\title{
The Effect of Hierarchical Word Activities on Written Expression Skills and Writing Anxiety in Turkish Language Education for Foreign Students
}

\author{
Ayşe Ateş ${ }^{1} \&$ Nesrin $\mathrm{Sis}^{2}$ \\ ${ }^{1}$ Turkish Language Learning Research and Application Center, Inonu University, Malatya, Turkey \\ ${ }^{2}$ Turkish Education Department, Faculty of Education, İnönü University, Malatya, Turkey \\ Correspondence: Ayşe Ateş, Turkish Language Learning Research and Application Center, Inonu University, \\ Malatya, Turkey. E-mail: ayse.ates@inonu.edu.tr
}

Received: January 15, 2021

doi:10.5539/ies.v14n5p158
Accepted: March 23, $2021 \quad$ Online Published: April 29, 2021

URL: https://doi.org/10.5539/ies.v14n5p158

\begin{abstract}
In the study, the effect of hierarchical vocabulary activities prepared in accordance with Gass's Second Language Acquisition Model developed by Ateş (2016) on students' written expression skills and writing anxiety was investigated. While the determined target words were taught to the experimental group with hierarchical vocabulary activities, the supervised group was kept in a regular diary. The method of the study consists of an experimental design with pre-test-post-test-measurement and supervised group. Experimental and supervised groups consisted of foreign students studying at Inonu-TÖMER in the 2017-2018 academic year. An essay was written to the students as a pre-test and a post-test, and the Writing Anxiety Scale was applied. No significant difference was found between the experimental and supervised groups of the Written Expression Rubric, which is used to score the compositions, in the pre-test and post-tests. It was concluded that the privatized instruction applied to both groups was beneficial for students' written expressions. There was a significant difference between the experimental and supervised groups in terms of Writing Anxiety Scale pre-test scores. It was determined that the writing anxiety of the experimental group was higher in the pre-test.
\end{abstract}

Keywords: Turkish language education, hierarchical word activities, written expression skills, writing anxiety, foreign students

\section{Introduction}

\subsection{Introduce the Problem}

The Teaching Turkish as a foreign language is currently in many fields through TÖMER and MEB. In this respect, it is inevitable that it is open to innovations. In the ever-changing and developing world, language teaching should not be done with an old and classical approach. With the presence of $Z$ books, it is important for the field to include listening, speaking, writing and reading skills as well as grammar in teaching and arranging them in a way that the student can understand and most importantly use. The multidimensional work done in the classroom positively affects the attention and learning of students who learn Turkish as a foreign language.

There are many methods and techniques to improve the writing skill, which is generally considered to be the most difficult task for the foreigners. Writing skills are very important for students to improve their written expression skills. Tiryaki (2013) stated that the purpose of developing writing skills in teaching Turkish as a foreign language is to enable individuals to translate their feelings and thoughts into writing in a planned manner in accordance with the linguistic characteristics of Turkish. According to the researcher, since the writing skill is applied, the individual can show the acquired knowledge in a concrete way. In addition, it is an important element in giving feedback about the language to the person and in identifying the deficiencies of the language. This skill requires a person's knowledge, level of comprehension, order in presentation, purpose, and a mental activity that she performs to put his/her ideas on the subject in writing. Boylu (2014) stated that there are various difficulties in acquiring writing skills both in the mother tongue and in a foreign language. Looking at the process and stages of acquiring writing skills, he stated that acquiring writing skills in foreign language learning is a longer and more difficult process than acquiring writing skills in the native language. Büyükikiz and Hasırc1 (2013) stated that in teaching Turkish as a foreign language, the target audience should be well known and the materials should be 
prepared according to the target audience. In the course materials prepared according to the target audience, the basic vocabulary should be given as a whole in a way that they are related to each other. On the other hand, one of the important issues in teaching Turkish to foreigners is writing anxiety. It is possible to say that writing anxiety, which is one of the issues that can significantly affect students 'writing skills, includes students' attitude towards writing self-efficacy motivation fear. Aydın and Ciğerci (2020) stated that students have difficulty in writing skills in foreign language teaching and they experience anxiety about writing. In this context, it is seen that students experience different problems in writing skills in teaching Turkish as a foreign language. According to them, one of these problems is the writing anxiety experienced by students.

With the realization of the research, the effect of hierarchical vocabulary activities not only on word learning but also on other skills will be measured. Language teaching will be beneficial in practice with the development and enrichment of vocabulary. The use of new methods and techniques in teaching Turkish as a foreign language and the question of which methods and techniques should be used, attracted the attention of the researchers. In this respect, hierarchical vocabulary activities, which are thought to bring a new breath to vocabulary teaching, were taken as basis in this study.

The answers to the question of how useful it can be in practice in teaching Turkish as a foreign language are sought through theses and articles. In this study, the relationship between the hierarchical vocabulary activities of students learning Turkish as a Foreign Language, and their writing skills and writing anxiety was investigated. The purpose of choosing this topic is that vocabulary teaching is generally given according to the classical education mentality. Among the many subjects that need to be taught, the word can be seen as the most underrated. However, the word is an important point in language teaching as it is the most basic building block of the sentence. In this respect, if word activities are taught with lessons arranged according to hierarchical vocabulary activities, it is thought that significant differences will occur between students' written expression skills and writing anxiety.

Teaching Turkish as a foreign language is an important field that needs to be supported with different methods and techniques in recent years. Hierarchical vocabulary activities are an activity consisting of 7 hierarchical activities prepared by Ateş (2016) in accordance with Gass's Second Language Acquisition Model. The importance of hierarchical vocabulary activities, which have proven useful in teaching many fields such as vocabulary, sentence, sentence order, phrase vocabulary, and grammar, is important for foreign students to learn Turkish in practice. In this study, it was aimed to investigate the effect of hierarchical vocabulary activities, which is a teaching method, on the written expression skills and writing anxiety of students who learn Turkish as a foreign language. For this purpose, the following questions were answered:

1) In terms of the results of the "Written Expression Rubric", is there a significant difference between the scores of the experimental and supervised groups in the pre-test and post-test?

2) Is there a significant difference between the experimental and supervised groups according to the scores obtained from the pre-test and post-test in terms of the results of the "Written Expression Rubric"?

3) In terms of the results of the Writing Anxiety Scale, is there a significant relationship between the experimental and supervised groups' pre-test and post-test scores?

4) In terms of the results of the Writing Anxiety Scale, is there a significant relationship between the experimental and supervised groups according to their pre-test and post-test scores?

5) In terms of the sub-dimensions of the Writing Anxiety Scale and the results of the Written Expression Rubric, is there a significant relationship between the pre-test and post-test scores of the experimental and supervised groups?

\section{Method}

This is a quantitative research. Pre-test and post-test were designed with an experimental strategy with examination group. This pattern, also known as pre-test-post-test supervised group random design, is one of the most frequently used experimental designs in education and psychology. Here, first, two groups are formed by random assignment from the previously determined sample pool (Büyüköztürk et al., 2014). The quasi-experimental model is applied in cases where the realization of the random rule, which should be followed in forming the experimental and control groups, is sometimes impossible, too difficult or unnecessary (Baştürk, 2009 , p. 41). In the research, the two classes were chosen as equivalent to each other. In the process of assigning these classes, the average achievement of the students at the B1 level was taken as basis. Both classes were chosen randomly as experiments and controls.

In the pre-test and post-test experimental design with experimental-control groups used in the study, students were told to write a composition as a pre-test and a post-test, and the Writing Anxiety Scale was applied. Written 
Expression Rubric was used for scoring the compositions. While the hierarchical vocabulary activities prepared by the researchers were performed in the experimental group, a regular diary was kept in the control group. Both groups voluntarily participated in the proceedings.

\subsection{Working Group}

The study group of the research consists of 28 foreign students studying at İnönü University TÖMER. Among the students studying at A and B sections in the 2017-2018 academic year, 7 (50.0\%) of the experimental group in section A were girls and $7(50.0 \%)$ were boys. It is observed that $4(28.6 \%)$ of the examination group in section B were girls and $10(71.4 \%)$ were boys. These two classes were preferred because the average achievement of the students in the groups at the B1 level was close (75-77\%). The fact that the other classes are not at the B1 level is also effective in choosing these two classes.

\subsection{Data Collection Means}

In this part, information about the data collection means determined in accordance with the purpose of the study was given. Data collection means such as hierarchical vocabulary activities, determination of words, lesson plans, graded planning key of written narration, determination of composition topics were explained one by one.

\subsubsection{Hierarchical Vocabulary Activities}

In the research, the hierarchical vocabulary activities developed by Ateş (2016) will be applied to the experimental group. Hierarchical vocabulary activities were created according to Gass's Second Language Acquisition Model. In this respect, it is necessary to refer to Gass's Second Language Acquisition Model in order to better understand the hierarchical vocabulary activities. There are five main levels of learning in this model. The formation of these main levels is essential for the formation of intermediate or preconditions. The model, which was founded by Gass in 1988 and expanded in 1997 and presented as a framework in 2008, has five main levels: apperceived input, comprehended input, intake, integration and output based on mixed approaches (Gass, 1988).

Apperceived Input: Gass (2008) named the first step of input use as apperceived input. Comprehended input is the process of understanding the relationship between past experiences and newly encountered knowledge. Actually, comprehensible input, in other words, is a material that has been noticed by the student for past experiences. Comprehension is an internal cognitive movement. It is the definition of linguistic figures by associating previous knowledge with new information.

Gass and Selinker (2008) stated that the difference between apperceived input and comprehended input is conceptualizing first, and they stated that apperceived input is the first factor that prepares the student for further analysis to be possible. For example, the student may perceive comparative vowel length as an important feature of language in apperceived input. However, in the comprehended input, the student has to face the task. The use of the vowel length in some important contexts is understood by the student in comprehended input. It is also characteristic of comprehended input to have a particular vowel length for a particular meaning.

For a better understanding of comprehended input, they give a specific example: Japanese use vowel length to discriminate the meaning of the word. For example, biru: to build, and bİru: beer. It is understandable that a student learning Japanese is aware of the difference in the meaning of the word upon this context. Then understanding the difference between biru, to build and the bİru, beer is a level of comprehension.

Stating that it is important to define the components of intake, Gass and Selinker (2008) stated that intake is a component that occurs where the psycho-grammar process occurs. Intake is where generalized grammatical rules often arise. This will be likely by generalization or so-called overgeneralization.

Gass (2008) stated that there should be at least two outputs after intake in a language. Improving the grammar and storage of knowledge of a person's second language is the necessity of integration. It should be said that integration consists of storing information and language knowledge of the target language.

Stating that the personality of the student is important in the output, Gass (2008) stated that verbal or written outputs are given. The student's output often equates their grammar. The output changes in the student's grammar are mostly understandable. These two should not be considered equivalent. Output is varied by many factors and does not exactly determine a person's grammar. Student individual differences are very important. For example, one needs to rely on their own competence to produce a new sentence in the target language.

The hierarchical vocabulary consists of 7 activities:

In the activity, a WhatsApp group was established to expose students to the target vocabulary frequently, and the words were shared here. Vocabulary was posted on the board in the classroom and students' domain created. Affect according to Gass, language and culture are shock, anxiety and impressive filter. These were taken into account in 
the classroom. Motivation was ensured and the level of anxiety was reduced. During the recruitment process of the previous knowledge, the teacher made use of short-term reminders of the current knowledge of the second language and the knowledge of the students' native languages. Attention is the last stage of apperceived input.

In fact, attracting the attention of the students has been possible with some complicated studies. The teacher had the opportunity to observe all students in the classroom and observed variations in the students' attention-building processes. Some students said, "Hmm, yes I got it" after short grammatical reminders to activate previous knowledge. For some students, attention lies in the frequency sheets hanged in the classroom. For some, it is hidden in an area of affect that is also supported by motivation. In the first activity, attention is drawn to whether the words are mentioned in the text or not (So far it is an apperceived input).

The implementation process of the comprehended input was divided into two parts. In the first part, there were activities related to the intermediate conditions, negotiation and the exchange of native speakers. In order for negotiation of meaning to occur, the target vocabulary was discussed with the activity sheets given in the classroom. It is very important for students to negotiate the meanings of the words/phrases and consequently to be supported by the native speaker in order to create comprehended input. First of all, an activity sheet that enables negotiations was prepared. During the implementation process of these activities, the teacher, who was a native speaker, corrected the mistakes and supported the corrections during the implementation process of the activity. The teacher also served as a source for a negotiation of meaning of the positive and negative additional confirmatory evidence that the students had.

In the implementation process of the second part of the comprehended input, an activity was applied based on universals and previous linguistic knowledge. For comprehended input, universals and prior knowledge should be used. For this reason, it was ensured that the students could understand the language better based on their previous knowledge in the target language. Examination of the target vocabulary and the students were asked to translate their words/phrases into different genres in the target language based on language universals. Thus, both the mother tongue and the second language knowledge of the students were applied to a small extent.

An activity was prepared where students can measure and analyze the information of D1 and D2 before intake so that they can learn the information more semantically. In this activity, students were asked to write the meaning, synonym or opposite meaning of the target vocabulary in the target language. In addition, students were asked to translate in a way that shows the knowledge of D1.

While preparing the effectiveness of intake, structures such as creating hypothesis, testing the hypothesis, rejecting, approving, and changing the components were taken into consideration. In this respect, an activity was made with sentences, which is the best way to convert knowledge into hypothesis. Students were told to make sentences. Thus, they had the opportunity to reject, change and approve each hypothesis they formed as a result of the feedback given by the teacher.

In integration, an activity was prepared on storage and grammar components. Gass and Selinker (2008) stated that students stored the information they obtained. Therefore, in this activity, it is stipulated that the information to be taken out of the storage will be classified in terms of meaning or grammar. In the integration activities, students were asked to classify their words and phrases in terms of meaning. In each integration activity, the student was also given the target vocabulary of the previous integration activity. Students' continuous classification of the ever-increasing target vocabulary in terms of meaning or grammar will both help to remind the words in terms of frequency and contribute to the intake of meanings.

Written figures were taken into consideration while preparing output activities. The best way to measure written language vocabulary is to use written figures.

Creative writing activities were made to get done by the students in output activities. It can be said that writing a composition with the structures and vocabulary determined by the student in the target language is beneficial to expand the use of the language. As a result, hierarchical vocabulary activities were created according to this model. Experimental group students were taught 90 predetermined words for 6 weeks according to their hierarchical vocabulary activitiesStudents were first informed about hierarchical vocabulary activities. How a lesson is taught and what to pay attention to is given above while explaining the model.

\subsubsection{Course Plans}

The lesson plan was prepared separately for each "word world" section. The course plan consists of three parts. The first part includes the name of the course and the unit, and concepts such as subject, text and class. In the second part, the teaching-learning model is Gass's Second Language Acquisition Model and the educational means used are Seven Climates Turkish Teaching Set B2 Level Textbook and hierarchical vocabulary activity 
sheets.

\subsubsection{Composition Topics}

A composition was written to the experimental and supervised groups as pre-test and post-test. Composition topics were prepared by taking into account the writing subjects in the Seven Climates B2 Turkish Course Book. Two composition subjects belonging to all text types were collected in a pool by the researchers. These compositions were shown to three instructors teaching foreign nationals who were working as lecturers in İnönü TÖMER, to a Ph.D Instructor working at İnönü University Turkish Education Department and to a teacher doing a doctorate in Turkish Education at the same university. As a result of the expert opinions received, necessary regulations were made in composition subjects and a total of thirteen composition topics were selected. Composition topics are as follows: 1. "It was a little past $12 \mathrm{o}$ 'clock at night. Ahmet was heading home fast because he left work late ..." write a story that begins with the sentence. (story type) 2. Tell the fairy tale "Little Red Riding Hood" in your own words. (tale) 3. Write an autobiography, including what you have heard from your family since your childhood. (autobiography) 4. Describe the life of someone who is famous in your country. (biography) 5. Describe a novel that you like reading. (novel) 6. Tell a joke that belongs to your culture. (joke) 7. Describe a moment you have experienced in Turkey. (memory) 8. Describe a trip you made with TÖMER. (travel article) 9. What do you do during the day? Write as if you are writing in your diary and also paying attention to the hours. (daily) 10 . Write your thoughts on the war in Syria. (article) 11. Write an event that interests you as a news . (news article) 12. Write an interview with a working person about their job. (interview text) 13 . Write a letter to someone you miss is at the distance (letter).

While applying the composition study, the following points were taken into consideration: Before the study, the students were given the papers with the composition subjects. Students, who were informed about composition writing techniques, wrote the essays during the lesson and when the instructor was in the classroom. It was ensured that students who wrote about one of the thirteen essay topics did not use a dictionary. The students were informed about the authenticity of the compositions.

\subsubsection{Written Expression Rubric Scoring Key}

The "Written Expression Rubric" developed by Büyükikiz (2011) was used to evaluate the compositions in the study. The rubric used in the study is composed of five parts and seventeen features. The reason for using this rubric in the study is that it is valid and reliable, which has been added to the literature at B2 level.

\subsubsection{Supervised Group Daily Writing Activities}

It can be defendable that it would be more appropriate to use a certain method and technique rather than classical training for the supervised group. In this respect, a diary was made to get written to the supervised group students in a planned and scheduled manner for 6 weeks. Feedback was given to the diaries every day by the researcher. The idea to get diary written will enrich the vocabulary can be accepted.

\subsubsection{Writing Anxiety Scale}

The "Writing Anxiety Scale for Turkish as a Foreign Language" developed by Aytan and Tunçel (2015) was used to measure writing anxiety. The consistency coefficient of the scale, which consists of four sub-dimensions, Cronbach Alpha internal consistency reliability measurement is 86 . Internal consistency coefficients for the dimensions were calculated as .93 for the first dimension, .84 for the second dimension, .84 for the third dimension and .84 for the final dimension.

\subsubsection{Determining the Words to Be Taught to Students}

All vocabulary items were removed from the "Word World" section in the Seven Climates B2 Turkish Book, which is one of the data collection tools. A total of 209 words and phrases were reduced to 90 in line with the expert opinions taken from four instructors working as lecturers at İnönü TÖMER. Eleven hierarchical vocabulary activities were applied in a total of six-week lessons. Each of these activities took a total of four lesson hours in the classroom. It was observed that the students generally gave positive reactions.

\subsubsection{Application of Pre-Test and Post-Test}

Data collection tools were prepared as described above. An essay was written to the students as a pre-test and a post-test. The composition issues remained the same in both the pre and post test. Again, the next day, the Writing Anxiety Scale was applied to the experimental and control groups. It is known that the scale and the compositions are at the appropriate level for the students. While hierarchical vocabulary activities were carried out to the experimental group students for 6 weeks, the words in the textbook were not specifically taught to the control group, only the diary was written. 


\section{Results}

In the Implications and conclusions are included in this section in accordance with the aims of the research. The analysis of the data in the study was analyzed using the SPSS 22.0 program. Number, percentage, mean and standard deviation were used as descriptive statistical methods. T-test was used to compare continuous quantitative data between two independent groups. The difference between repeated measurements within the experimental and supervised groups were analyzed by the paired group t-test.

Table 1. Writing anxiety and written expression skills according to groups

\begin{tabular}{lcccccc}
\hline \multirow{2}{*}{ Groups } & \multicolumn{2}{c}{ Test $(\mathrm{n}=14)$} & \multicolumn{2}{c}{ Control $(\mathrm{n}=14)$} & \multirow{2}{*}{$\mathrm{t}$} & $\mathrm{p}$ \\
\cline { 2 - 6 } & Ort & $\mathrm{Ss}$ & Ort & $\mathrm{Ss}$ & & \\
\hline Grammar and Writing Perception Pre-test & 49.143 & 4.185 & 37.714 & 9.360 & 4.171 & 0.001 \\
Attitude towards Writing Pre-test & 20.643 & 3.586 & 18.214 & 3.683 & 1.768 & 0.089 \\
In-Class Activities Pre-test & 15.786 & 1.762 & 14.429 & 2.174 & 1.815 & 0.081 \\
Self-Efficacy Writing Pre-test & 30.571 & 2.377 & 26.643 & 8.073 & 1.747 & 0.101 \\
Writing Anxiety Pre-test & 116.143 & 7.451 & 97.000 & 21.616 & 3.133 & 0.006 \\
Written Expression Skills Pre-test & 26.000 & 10.962 & 28.214 & 9.545 & -0.570 & 0.574 \\
Grammar and Writing Perception Post-test & 46.429 & 3.995 & 45.571 & 5.155 & 0.492 & 0.627 \\
Attitude towards Writing Post-test & 22.357 & 2.134 & 21.286 & 2.758 & 1.150 & 0.261 \\
In-Class Activities Post-test & 16.714 & 1.899 & 16.143 & 1.995 & 0.776 & 0.444 \\
Self-Efficacy Writing Post-test & 29.929 & 3.050 & 31.786 & 4.228 & -1.333 & 0.194 \\
Writing Anxiety Post-test & 115.429 & 7.418 & 114.786 & 7.607 & 0.226 & 0.823 \\
Written Expression Skills Post-test & 44.929 & 11.705 & 39.429 & 12.457 & 1.204 & 0.239 \\
\hline
\end{tabular}

According to Table 1, the grammar and writing perception pre-test scores of the students differ significantly according to the groups $\left(\mathrm{t}_{(26)}=4.171 ; \mathrm{p}=0.001<0.05\right)$. The grammar and writing perception pre-test scores of the experimental group $(\overline{\mathrm{x}}=49.143)$ were found higher than the grammar and writing perception pre-test scores of the supervised group $(\mathrm{x})=37.714)$.

Students' writing anxiety pre-test scores differ significantly according to the groups $\left(\mathrm{t}_{(26)}=3.133 ; \mathrm{p}=0.006<\right.$ $0.05)$. The writing anxiety pre-test scores of the experimental group $(\overline{\mathrm{x}}=116.143)$ were higher than the writing anxiety pre-test scores $(\overline{\mathrm{x}}=7.000)$ of the supervised group.

Students' writing attitude pre-test, classroom activities pre-test, writing self-efficacy pre-test, written expression skill pre-test, grammar and writing perception post-test, writing attitude post-test, classroom activities post-test, writing self-efficacy post-test, Writing anxiety post-test, written expression skills post-test scores do not differ significantly according to the group variable $(\mathrm{p}>0.05)$.

Table 2. Experiment group writing anxiety and written expression skills difference between pre-test and post-test scores

\begin{tabular}{lccccccc}
\hline \multirow{2}{*}{ Measurements } & \multicolumn{2}{c}{ Pre-test } & \multicolumn{2}{c}{ Post-test } & \multirow{2}{*}{ N } & t & p \\
\cline { 2 - 6 } & Avg & Ss & Avg & Ss & & & \\
\hline Grammar and Writing Perception & 49.143 & 4.185 & 46.429 & 3.995 & 14 & 1.917 & 0.077 \\
Attitude Towards Writing & 20.643 & 3.586 & 22.357 & 2.134 & 14 & -1.674 & 0.118 \\
Classroom Activities & 15.786 & 1.762 & 16.714 & 1.899 & 14 & -1.869 & 0.084 \\
Writing Self-Efficacy & 30.571 & 2.377 & 29.929 & 3.050 & 14 & 0.730 & 0.478 \\
Writing Anxiety & 116.143 & 7.451 & 115.429 & 7.418 & 14 & 0.335 & 0.743 \\
Written Expression Skills & 26.000 & 10.962 & 44.929 & 11.705 & 14 & -11.432 & 0.000 \\
\hline
\end{tabular}

According to Table 2, the difference between arithmetic means was found statistically significant as a result of the paired group t-test performed to determine whether the pre-test for written expression skills and the post-test for written expression skills in the experimental group showed a significant difference $\left(\mathrm{t}_{(13)}=-11.432 ; \mathrm{p}=0.000<0.05\right)$. 
Pre-test average of written expression skill $(\overline{\mathrm{x}}=26.000)$ is lower than the average of written expression skills post-test $(\overline{\mathrm{x}}=44.929)$.

In the experimental group, grammar and writing perception pre-test, grammar and writing perception post-test, attitude towards writing pre-test with attitude towards writing post-test, classroom activities pre-test with classroom activities post-test, writing self-efficacy pre-test and writing self-efficacy post-test As a result of the paired group t-test performed to determine whether the mean scores of the test, writing anxiety pre-test and writing anxiety post-test differ significantly, the difference between the arithmetic averages was not found to be statistically significant $(\mathrm{p}>0.05)$.

Table 3. Difference between supervised group writing anxiety and written

\begin{tabular}{lccccccc}
\hline \multirow{2}{*}{ Measurements } & \multicolumn{2}{c}{ Pre-test } & \multicolumn{3}{c}{ Post-test } & \multirow{2}{*}{ N } & p \\
\cline { 2 - 7 } & Avg & Ss & Avg & Ss & & \\
\hline Grammar and Writing Perception & 37.714 & 9.360 & 45.571 & 5.155 & 14 & -3.256 & 0.006 \\
Attitude Towards Writing & 18.214 & 3.683 & 21.286 & 2.758 & 14 & -2.536 & 0.025 \\
Classroom Activities & 14.429 & 2.174 & 16.143 & 1.995 & 14 & -1.871 & 0.084 \\
Writing Self-Efficacy & 26.643 & 8.073 & 31.786 & 4.228 & 14 & -2.006 & 0.066 \\
Writing Anxiety & 97.000 & 21.616 & 114.786 & 7.607 & 14 & -3.186 & 0.007 \\
Written Expression Skills & 28.214 & 9.545 & 39.429 & 12.457 & 14 & -4.934 & 0.000 \\
\hline
\end{tabular}

According to Table 3, as a result of the paired group t-test performed to determine whether the grammar and writing perception pre-test and the grammar and writing perception post-test averages show a significant difference in the supervised group, the difference between the arithmetic means was found to be statistically significant $\left(\mathrm{t}_{(13)}=-3.256 ; \mathrm{p}=0.006<0.05\right)$. Grammar and Writing Perception Pre-test average $(\overline{\mathrm{x}}=37.714)$ is lower than the post-test average $(\overline{\mathrm{x}}=45.571)$.

Attitude Towards Writing in the supervised group, as a result of the paired group t-test conducted to determine whether the pre-test and post-test means of attitudes towards writing show a significant difference, the difference between the arithmetic means was found to be statistically significant $\left(\mathrm{t}_{(13)}=-2.536 ; \mathrm{p}=0.025<0.05\right)$. The pre-test mean $(\overline{\mathrm{x}}=18.214)$ is lower than the post-test average of Attitude Towards Writing $(\overline{\mathrm{x}}=21.286)$.

As a result of the paired group t-test performed to determine whether the writing anxiety pre-test and writing anxiety post-test mean differ significantly in the supervised group, the difference between the arithmetic averages was found to be statistically significant $\left(\mathrm{t}_{(13)}=-3.186 ; \mathrm{p}=0.007<0.05\right)$. Writing Anxiety's pre-test average $(\overline{\mathrm{x}}=$ $97.00)$ is lower than the writing anxiety post-test average $(\overline{\mathrm{x}}=114.786)$.

As a result of the paired group t-test performed to determine the pre-test and written expression skills post-test averages show a significant difference in the supervised group, the difference between the arithmetic averages was found to be statistically significant $\left(\mathrm{t}_{(13)}=-4.934 ; \mathrm{p}=0.000<0.05\right)$. Written Expression Skills Pre-test average $(\overline{\mathrm{x}}=$ $28.214)$ is lower than the post-test average of written expression skill $(\overline{\mathrm{x}}=39.429)$.

In the supervised group, classroom activities pre-test, classroom activities post-test, writing self-efficacy and the paired group t-test, which was conducted to determine the significant differences of the pre-test and writing self-efficacy post-test means, did not find the statistically significant difference between arithmetic averages ( $\mathrm{p}>$ $0.05)$.

\section{Discussion}

In this study, it can be said that the hierarchical vocabulary prepared in accordance with the Gass's Second Language Acquisition Model has a positive effect on students' written expressions and writing anxiety. In terms of the results of the Written Expression Rubric, the scores of the experimental group from the pre-test and post-test are significant $\left(\mathrm{t}_{(13)}=-11.432 ; \mathrm{p}=0.000<0.05\right)$. The activities based on the hierarchical vocabulary applied to the experimental group contributed to the students' written expressions. On the other hand, the results of the Written Expression Rubric applied to the supervised group are similar to the experimental group. It was concluded that the diary writing applied to the supervised group also contributed to the written expressions of the students $\left(\mathrm{t}_{(13)}=-4.934 ; \mathrm{p}=0.000<0.05\right)$. Although there was no significant difference between the experimental and supervised groups in terms of pre-test and post-tests of the Written Expression Rubric, it was concluded that the customized instruction applied to both groups was beneficial. Lin and Hsu (2013) studied the acquisition of 
vocabulary and reading comprehension in their study, in which they measured the effectiveness of hierarchical vocabulary exercises. They found a positive relationship between students' vocabulary knowledge and reading comprehension skills. Based on their results, it can be concluded that the hierarchical vocabulary activities in the experimental group of this study increased the success rate. Ateş (2016), in her thesis, in which she investigated the effect of hierarchical vocabulary activities on vocabulary, found that the experimental group's score averages for the target words not only achieved the success of the supervised group in the pre-test but even exceeded the success rate. Based on this, it should be emphasized that the hierarchical vocabulary activities prepared on the basis of Gass's Second Language Acquisition Model for target words contribute to achieving success. It should also be said that the results are similar between Ateş's (2016) study and this study. In her study, the difference between the total post-test scores of the groups regarding the target vocabulary was found to be significant in favor of the experimental group. In addition, the difference between the mean retention test scores of the target vocabulary was found to be significantly higher in favor of the experimental group. In this study, although there is no meaningful result in terms of written expression evaluation form in favor of the experimental group, it would be correct and appropriate to talk about a rise among the group. Paribakht and Wesche (1993) studied the classification scheme used in the selection of vocabulary exercise types for this experiment, its development and its subsequent refinement in the context of on going research. They used the classification scheme represents a hypothesized hierarchy of the degree and type of mental processing required by various kinds of vocabulary exercises, in accordance with current understanding of .how learners acquire new knowledge of the target language from novel input (cf. Gass 1988). Development procedures included a comprehensive review of ESL vocabulary textbooks to collect reading-based exercises, analysis and cateorization of exercises, and selection of key types meeting specified criteria. The categories are: 1) selective attention to specific words through visual signalling, 2) recognition of target words and their meanings, 3) grammatical and morphological manipulation of words and word elements in context, 4) interpretation of word meanings in relation to other words or disconrse functions, and 5) production of the target word in appropriate contexts (Paribakht \& Wesche, 1993, p. 2).

Paribakht and Wesche (1994) indicated that both reading and reading accompanied by text-based vocabulary exercises lead to substantial vocabulary knowledge gains, the latter leads to more favorable outcomes. They said however, the processes by which these occur are not clear. By shedding some light on the way acquisition of vocabulary knowledge takes place through reading comprehension and doing vocabulary exercises, it may be possible to enhance these processes and make instruction more efficient.

Paribakht and Wesche (1999) aimed to gain new vocabulary by reading texts thematically in their work. In their research, they asked students to learn new words they encountered while reading a text in classes where English as a Second Language was taught. Students used the basic strategy of inference to find the meanings of the words in the text. They interpreted the findings in terms of current research and theory on random word acquisition within the framework of input-processing. As a result, they found that random word acquisition plays an important role in second language acquisition by teaching with a specific theme. Our research is in parallel with this research. As a matter of fact, the hierarchical vocabulary activities created based on Gass's second language acquisition model are also aimed at improving students' vocabulary knowledge. The same researchers' Paribakht and Wesche (1993) focused on comprehension activity in another article. They followed 37 intermediate English learners in a program that focused on comprehension activities in their articles. The main purpose of the study was to develop a suitable methodology and tools for classes. As a result, they gained more in vocabulary in comprehension-based activities. In the hierarchical vocabulary activities which are the subject of our article, gains have been obtained in vocabulary as well. In addition, these researches are very important in terms of finding suitable methods and techniques for classes.

Zhang (2009), on the other hand, looked at the role of input, interaction and output in the development of oral fluency in teaching English as a second language, both from a theoretical point of view and through a case study. The researcher conducted oral fluency tests and face-to-face interviews as data collection techniques. In the findings, the researcher found that students lacked effective input and output, did not need any real interaction, and did not pay much attention to language forms and written tests. However, it can be said that students learning foreign languages have effective input and output with hierarchical vocabulary activities.

Mackey, Gass, and Mcdonough (2000) mentioned theoretical claims about the benefits of speech interaction in their articles. In this study, which was about students' receiving feedback about their speech during interaction and how they perceive these feedbacks, researchers worked with ten students who learned English as a second language? They had the students watch videotapes before the interaction and when the interaction took place, they encouraged the students to research. As a result, it was revealed that the students perceived the semantic and formal feedbacks but did not fully perceive the semantic form. In our article, it was seen that when we take the 
input word presence as output, students understand it in terms of semantics and form.

In this regard, it should be said that new and different technical methods should be used. As a matter of fact, the classical understanding of education in which the student does not participate in the class but is passive has become history. In this respect, hierarchical vocabulary activities are important and new. It can also be said that diary writing is a complete utilizable technique.

The results of the Writing Anxiety Scale, which was applied to see how much writing anxiety has affected the students through the lessons applied, is also positive for both groups. Students' writing anxiety pre-test scores differ significantly according to the groups $\left(\mathrm{t}_{(26)}=3.133 ; \mathrm{p}=0.006<0.05\right)$. There was a significant difference between the experimental and supervised groups in terms of writing anxiety pre-test scores. It was determined that the writing anxiety of the experimental group was higher in the pre-test. However, this situation did not make a significant difference in the post-test. Although the experimental group scores lower on the writing anxiety scale than the pre-test; Even if the supervised group also get higher scores, these are not significant. When the supervised group writing anxiety pre-test and post-test averages were examined, it was seen that there was a significant difference $\left(\mathrm{t}_{(13)}=-3.186 ; \mathrm{p}=0.007<0.05\right)$. It was concluded that the supervised group reduced the writing anxiety by writing a diary. Therefore, it can be concluded that the hierarchical vocabulary activities and dairy writing activities did not affect writing anxiety enough to make a significant difference.

The relationship between students' writing anxiety sub-dimensions (grammar, classroom activities, writing perception and writing attitude) and their written expressions were also examined. Students' grammar and writing perception pre-test scores differ significantly according to the groups $\left(\mathrm{t}_{(26)}=4.171 ; \mathrm{p}=0.001<0.05\right)$. Grammar and writing perception pre-test and post-test averages showed a significant difference in the supervised group $\left(\mathrm{t}_{(13)}=-3.256 ; \mathrm{p}=0.006<0.05\right)$. Grammar and writing perception pre-test average was lower than the post-test average. In the supervised group, the pre-test and post-test averages showed a significant difference in the sub-dimension of writing $\left(\mathrm{t}_{(13)}=-2.536 ; \mathrm{p}=0.025<0.05\right)$. The pre-test mean of writing attitude was lower than the post-test average. In this respect, it can be said that there is a partial significant relationship between the sub-dimensions of writing anxiety and written expression skills in the supervised group.

\section{Acknowledgments}

This work has been financially supported by Inonu University (project number: SBA-2018-1246). A part of this study was presented as a paper at XI International Congress on Education and Teaching of Turkish (2018).

\section{References}

Ateş, A. (2016). The effect of Gass's Second Language Acquisition Model on improving vocabulary in teaching Turkish to foreigners (Doctoral thesis, Inonu University, Institute of Educational Sciences, Malatya).

Aydın, E., \& Ciğerci, F. M. (2020). The effect of digital storytelling on writing anxiety in teaching Turkish to foreigners. Journal of History School, 45, 1078-1097. https://doi.org/10.29228/joh.41513

Aytan, N., \& Tunçel, H. (2015). Development of a Turkish as a foreign language writing anxiety scale. Mustafa Kemal University, Bulletin of Social Sciences Institute, 12(30), 50-62.

Baştürk, R. (2009). Trial Models. In A. Tanriöğen (Ed.), Scientific research methods (pp. 31-53). Ankara. Anı Publishing.

Boylu, E. (2014). The writing problems of Iranian students in the basic level who learns Turkish as a foreign language. Zeitschrift für die Welt der Türken Journal of World of Turks, 6(2), 335-349.

Büyükikiz, K. K. (2011). A research on the relationship between writing skills and self-efficacy perceptions of those who learn Turkish as a foreign language (Doctoral dissertation, Gazi University Institute of Educational Sciences, Ankara).

Büyükikiz, K., \& Hasırc1, S. (2013). An evaluation of vocabulary teaching on Turkish teaching as a foreign language. Mustafa Kemal University Journal of Social Sciences Institute, 10(21), 145-155.

Büyüköztürk, Ş., Kılıç Çakmak, E., Akgün, Ö. E., Karadeniz, Ş., \& Demirel, F. (2014). Scientific research methods (21st ed.). Ankara: Pegem Publications.

Gass, S. M. (1988). Integrating research areas: A framework for second language studies. Applied linguistics, 9(2), 198-217. https://doi.org/10.1093/applin/9.2.198

Gass, S., \& Selinker, L. (2008). Second language acquisition an introductory course. Library of Congress Cataloging in Publication Data, New York.

Lin, C. Y., \& Hsu, W. S. (2013). Effects of Hierarchy Vocabulary Exercises on English Vocabulary Acquisition. 
English Language Teaching, 6(9), 110-119. https://doi.org/10.5539/elt.v6n9p110

Mackey, A., Gass, S., \& McDonough, K. (2000). How do learners perceive interactional feedback?. Studies in second language acquisition, 22(4), 471-497. https://doi.org/10.1017/S0272263100004010

Paribakht, T. S., \& Wesche, M. (1999). Reading and "incidental" 12 vocabulary acquisition an introspective study of lexical inferencing. Social Sciences and Humanities Research Council of Canada, 21(2), 195-204. https://doi.org/10.1017/S027226319900203X

Paribakht, T., \& Wesche, M. (1993). Reading Comprehension and Second Language Development in a Comprehension-Based ESL Program. TESL Canada Journal, 11(1), 9-29. https://doi.org/10.18806/tesl.v11i1.623

Tiryaki, E. N. (2013). Writing education in teaching Turkish as a foreign language. Journal of Mother Tongue Education, 1(1), 38-44.

Wesche, M., \& Paribakht, T. S. (1994). Enhancing vocabulary acquisition through reading: a hierarchy of text-related exercise types. Paper presented at the Annual Meeting of the American Association for Applied Linguistics (Baltimore, MD, March 5-8, 1994).

Zhang, S. (2009). The Role of Input, Interaction and Output in the Development of Oral Fluency. English Language Teaching, 2(4), 91-100. https://doi.org/10.5539/elt.v2n4p91

\section{Copyrights}

Copyright for this article is retained by the author(s), with first publication rights granted to the journal.

This is an open-access article distributed under the terms and conditions of the Creative Commons Attribution license (http://creativecommons.org/licenses/by/4.0/). 